\title{
ANALYSIS ON CFC RULES IN INDONESIA AND CHINA AS WELL AS BPEPS ACTION PLAN 3 IN THE EFFORT OF STRENGTHENING CFC RULES IN INDONESIA
}

\author{
Nur Afianti Fajriyan \\ Master in Administrative Sciences, \\ Department of Administration, Faculty of \\ Administration, Universitas Indonesia \\ e-mail : nurafianti63@gmail.com
}

\section{ABSTRACT}

The emergence of multinational companies (MNC), as the impact of increasingly globalized world's economic system and changes to tax regulations that are not in line with the globalization development, has given opportunity to $\mathrm{MNC}$ to perform international tax avoidance. One of the tax avoidance practices done by $\mathrm{MNC}$ is establishing CFC (Controlled Foreign Companies) for avoiding domestic tax imposition. The rampant issue of $\mathrm{CFC}$ establishment for tax avoidance has resulted in the OECD and G20 making BEPS (Base Erosion and Profit Shifting) Action Plan 3 containing recommendations for the strengthening of CFC rules. This Action Plan was expected to be adopted by all member states including Indonesia. As follow-up to it, Indonesia has issued new $\mathrm{CFC}$ rules as set out in Regulation of the Minister of Finance number: PMK No.107/PMK.03/2017, dated July 27, 2017. Similar to Indonesia, China also has CFC rules in the effort of preventing tax avoidance practices. This research was aimed at comparing the $\mathrm{CFC}$ rules in Indonesia with the CFC rules in China seen from the aspect of type of control, the aspect of shareholding limit in determining joint ownership with other resident taxpayers, the aspect of definition of low tax jurisdiction, and the aspect of exemption.

This research used qualitative approach with descriptive research type. Data collecting methods used were literature study and field study through in-depth interview with related stakeholders.

The research result shows that compared to China, the CFC rules in Indonesia still have weaknesses seen from 4 aspects, namely the
Ning Rahayu

The Department of Administration, Faculty of Administration, Universitas Indonesia e-mail :ning.rahayu@gmail.com

aspect of type of control, the aspect of shareholding limit in determining joint ownership with other resident taxpayers, the aspect of definition of low tax jurisdiction, and the aspect of exemption. To render the CFC rules in Indonesia effective and efficient in preventing tax avoidance, the weaknesses of the CFC rules can be remedied by way of applying control test that is not only based upon legal control in the form of shares, making shareholding limit in determining joint ownership with other resident taxpayers, making definition of low tax jurisdiction, applying genuine economic exemption and motive exemption. Keywords: Tax Avoidance, CFC rules, Action Plan 3 BEPS

\section{INTRODUCTION}

\section{A. Preface}

Globalization has been taking place in almost every aspect of human life including economy. One of the significant characteristics of globalization of the economic system of a state is the increase in FDI (Foreign Direct Investment) (Rahayu, 2008). FDI is divided into inward FDI and outward FDI. Indonesia and China are G20 members in Asia that are not free from the impacts of economic globalization. Based on the World Investment report (2017), the outward outflows in Indonesia and China within the past 6 (six) years have been in increasing trend, as follows:

\section{Table 1}

Outward Outflows in Indonesia and China (In Millions of Dollar)

\begin{tabular}{|c|c|c|}
\hline \multirow{2}{*}{ Year } & \multicolumn{2}{|c|}{ Outward Outflows } \\
\cline { 2 - 3 } & Indonesia & China \\
\hline
\end{tabular}




\begin{tabular}{|c|c|c|}
\hline 2011 & 7,713 & 74,654 \\
\hline 2012 & 5,422 & 87,804 \\
\hline 2013 & 6,647 & 107,844 \\
\hline 2014 & 7,077 & 123,120 \\
\hline 2015 & 5,937 & 127,560 \\
\hline 2016 & 12,463 & 183,100 \\
\hline
\end{tabular}

Source: World Investment report 2017 on investment and the digital economy. United Nations Conference on Trade and development, 2017.

unctad.org/en/PublicationsLibrary/wir2017 _en.pdf

Based on the table above, there has been an increasing trend of outward outflows in Indonesia from 2012 to 2017, with the exemption of the year 2016, where there had been a decreasing trend. China was a state with the highest level of outward outflows in Asia in 2015 and 2016. The increasing trend of outward FDI on the one hand is expected to broaden state's access to international market so as to increase state's export and foreign exchange (Gunadi, 2007), but on the other hand is potential of increasing tax avoidance practices through the establishment of controlled entities or more commonly known as CFC (Controlled Foreign Companies).

The establishment of CFC may results in tax avoidance due to different tax treatments on the income received by resident taxpayers from subsidiaries and from company branches. In general, outward FDI can be performed through the establishment of subsidiaries and company branches. Income from company branches shall be imposed with tax on a current basis because branches and the head office are considered as a single entity, therefore the company's branches may not postpone profit sharing (Gunadi, 2007). Income from subsidiaries shall be imposed with tax on a cash basis because subsidiaries and the parent company are considered as separate entities; therefore subsidiaries may postpone profit sharing (Gunadi, 2007). Continuous and sustainable postponement of taxation shall result in elimination of taxation by Indonesia (Gunadi, 2007). In order to prevent tax deferral through the establishment of CFC, a number of states applying worldwide income taxation basis have established CFC rules including Indonesia and China.

Without changes for almost 10 years, the CFC rules in Indonesia existing in Regulation of the Minister of Finance No.256/PMK.03/2008 (hereinafter referred to as PMK-256) regarding Deemed Dividends by Resident Taxpayers upon Capital Investment in Non-Listed Overseas Business for Capital Participation in Overseas Business Entities, have many loopholes and are irrelevant to the current business model. As an effort of establishing CFC rules that are more effective in preventing tax avoidance, the government has issued Regulation of the Minister of Finance No. 107/PMK.03/2017 (hereinafter referred to as PMK-107), dated July 27, 2017 regarding Deemed Dividends and Their Bases of Calculation by Resident Taxpayers for Capital Participation in Overseas Business Entities Other than Listed Business Entities, in Lieu of PMK256. There is a quite significant difference between PMK-256 and PMK-107, among others on the definition of control. However, there are still weaknesses in PMK-256 that have not been remedied in PMK-107, rendering PMK-107 less effective as an antitax avoidance. One of the most concrete weaknesses of PMK-107 is the absence of definition of low tax jurisdiction, resulting in the application of PMK-107 towards all the CFC controlled by resident taxpayers in all states without due consideration of the tax rates in the countries where the relevant CFC are located. Remedying all weaknesses of a regulation is an important thing to do for such regulation to function as desired.

In order to analyze the weaknesses or deficiencies of a regulation, one of the methods that can be done is comparing the relevant regulation with similar regulations existing in other states. The CFC rules in China have been selected as a comparator in analyzing the weaknesses of the CFC rules in Indonesia due to a number of reasons, among others, the broader application of the CFC rules in China as they cover legal control and effective control and their more 
targeted application as they are only applied towards the CFC located in low tax jurisdictions. Analysis on such comparisons is expected to be used as reference in remedying the weaknesses of the $\mathrm{CFC}$ rules in Indonesia.

The rampant issue of tax avoidance through the establishment of CFC has resulted in many states in the world potential of losing tax revenues due to base erosion as well as profit shifting to the states having lower tax rates or more commonly known as BEPS (Base erosion and Profit Shifting). In order to avoid the occurrence of BEPS particularly through CFC, the OECD and G20 have publicized Action Plan 3 containing recommendations for the strengthening of CFC rules. Such recommendations are expected to be adopted by all member states for rendering the $\mathrm{CFC}$ rules owned more effective in preventing tax avoidance practices. As a member of G20, Indonesia may adopt such recommendations by first adjusting them to domestic tax regulations. Based on the above elaboration, this research is also aimed at analyzing how far PMK-107 has been in accordance with the recommendations in the Action Plan 3 of the OECD and G20 in strengthening CFC rules.

\section{B. Theoritical Framework Tax Haven Countries}

According to Gunadi (2003) tax haven is a country having policy to collect taxes at a low to non-existent rate. Tax haven has a number of characteristics, among others the absence of tax collection, however if collection is done, the rates charged are very low, strict bank confidentiality due to highly strict confidentiality regulating rules, the availability of modern communication devices, loose control over foreign exchange and deposit, and the availability of advertisement on tax haven countries as sound and secured financial hubs (Zain, 2005).

\section{Tax Avoidance and Tax Evasion}

Tax avoidance according to Rohatgi (2002) is divided in two, namely acceptable tax avoidance defined as the activity of reducing tax burden by arranging a person's movement (or non-movement), transactions or funding, or other activities within the corridor of laws and regulations, and unacceptable tax avoidance, defined as the activity of reducing tax burden by arranging correct and legal transactions but by involving tax structure-related fraud or forgery (Rohatgi, 2002).

\section{CFC (Controlled Foreign Companies) Rules}

Dado and Sedmihradsky in Lang, Aigner, Scheuerle and Stafaner (2004) explained that CFC are overseas entities controlled by resident taxpayers, where the relevant CFC term is used in the context of a regime designed to strike the profit stopover from resident taxpayers to the places applying low tax rates or not apply taxes. According to Arnold and Dibout (2001), CFC rules are the rules used for limiting or eliminating the postponement of tax obligations of resident taxpayers receiving income from overseas entities.

\section{Approach in preparing CFC rules}

There are two approaches in preparing CFC rules, namely designated jurisdiction approach and global approach. According to Arnold and McIntyre (2002), designated jurisdiction approach is implemented using a list of countries where CFC rules shall be applied towards the entire income received from the CFC located in the countries on the list. According to Pinto (2003), global approach focuses on the application of CFC rules based on the effective tax rate charged on overseas income (passive income) received by shareholders.

\section{Determination of Income included in $\mathrm{CFC}$ rules}

In making definition of $\mathrm{CFC}$ income, two approaches can be used, namely entity approach and transactional approach. According to Pinto (2003), entity approach is an approach implemented by making threshold on the amount of CFC's (passive) income. Transactional approach according to Pinto (2003) focuses on the income received by CFC based on each carried out transaction. If the relevant transaction contains any passive income or tainted income, CFC rules shall be applied, while if the income received by $\mathrm{CFC}$ derives from 
active income, CFC rules shall not be applied.

\section{Defferal}

According to Arnold (1986), deferral shall bring benefit when overseas income become tax object in the countries where shareholders are located and the effective tax rate charged overseas are lower than the tax rate in the domestic countries of shareholders.

\section{RESEARCH METHOD}

The research approach used is qualitative approach with descriptive research type. Data collecting in this research shall be carried out in two methods, namely through literature study and field study. Literature study shall be done by reading books, journals and others related to CFC, while field study shall be done through in-depth interviews with related stakeholders, namely the Directorate General of Taxation, tax consultants, and taxation academicians. After data have been collected, analysis shall be done by using a number of CFC-related theories.

\section{DISCUSSION AND ANALYSIS}

\section{Analysis on the Weaknesses of PMK-107}

Before conducting analysis on the weaknesses on PMK-107, comparison shall be first made between PMK-256 and PMK107 presented in table 2 below:

Table 2

Comparison between PMK-256 and PMK-107

\begin{tabular}{|c|c|c|c|c|}
\hline \multirow{2}{*}{$\begin{array}{l}\text { Compa } \\
\text { rative } \\
\text { Aspects }\end{array}$} & \multicolumn{2}{|c|}{ PMK-256 } & \multicolumn{2}{|c|}{ PMK-107 } \\
\hline & $\begin{array}{c}\text { Provisi } \\
\text { ons }\end{array}$ & $\begin{array}{c}\text { Weakne } \\
\text { sses }\end{array}$ & $\begin{array}{c}\text { Provisi } \\
\text { ons }\end{array}$ & $\begin{array}{c}\text { Weakne } \\
\text { sses }\end{array}$ \\
\hline $\begin{array}{l}\text { Definiti } \\
\text { on of } \\
\text { control }\end{array}$ & $\begin{array}{l}\text { Minim } \\
\text { um } \\
50 \% \\
\text { direct } \\
\text { share } \\
\text { partici } \\
\text { pation } \\
\text { in an } \\
\text { overse } \\
\text { as non- } \\
\text { stock } \\
\text { exchan } \\
\text { ge }\end{array}$ & $\begin{array}{l}\text { Tax } \\
\text { avoidan } \\
\text { ce can } \\
\text { be done } \\
\text { by } \\
\text { perform } \\
\text { ing } \\
\text { control } \\
\text { through } \\
\text { artificial } \\
\text { share } \\
\text { ownersh } \\
\text { ip }\end{array}$ & $\begin{array}{l}\text { Minim } \\
\text { um } \\
50 \% \\
\text { direct } \\
\text { and } \\
\text { indirec } \\
\text { t share } \\
\text { partici } \\
\text { pation } \\
\text { in an } \\
\text { overse } \\
\text { as non- } \\
\text { stock }\end{array}$ & - \\
\hline
\end{tabular}

\begin{tabular}{|c|c|c|c|c|}
\hline & $\begin{array}{l}\text { busines } \\
\text { s entity }\end{array}$ & & $\begin{array}{l}\text { exchan } \\
\text { ge } \\
\text { busines } \\
\text { s entity }\end{array}$ & \\
\hline $\begin{array}{l}\text { Type of } \\
\text { control }\end{array}$ & $\begin{array}{l}\text { Legal } \\
\text { control } \\
\text { in the } \\
\text { form of } \\
\text { shares }\end{array}$ & $\begin{array}{l}\text { Tax } \\
\text { avoidan } \\
\text { ce can } \\
\text { be done } \\
\text { through } \\
\text { control } \\
\text { in forms } \\
\text { other } \\
\text { than } \\
\text { shares }\end{array}$ & $\begin{array}{l}\text { Legal } \\
\text { control } \\
\text { in the } \\
\text { form of } \\
\text { shares }\end{array}$ & $\begin{array}{l}\text { Legal } \\
\text { control } \\
\text { in the } \\
\text { form of } \\
\text { shares }\end{array}$ \\
\hline $\begin{array}{l}\text { Shareh } \\
\text { olding } \\
\text { minimu } \\
\text { m limit } \\
\text { in } \\
\text { determi } \\
\text { ning } \\
\text { joint } \\
\text { owners } \\
\text { hip } \\
\text { with } \\
\text { other } \\
\text { resident } \\
\text { taxpaye } \\
\text { rs }\end{array}$ & N/A & $\begin{array}{l}\text { Render } \\
\text { control } \\
\text { difficult } \\
\text { to be } \\
\text { done } \\
\text { and not } \\
\text { quite } \\
\text { suitable } \\
\text { with the } \\
\text { principl } \\
\text { e of } \\
\text { ease of } \\
\text { administ } \\
\text { ration in } \\
\text { tax } \\
\text { collectio } \\
\text { n. } \\
\text { pemung } \\
\text { utan } \\
\text { pajak }\end{array}$ & N/A & $\begin{array}{l}\text { Render } \\
\text { control } \\
\text { difficult } \\
\text { to be } \\
\text { done } \\
\text { and not } \\
\text { quite } \\
\text { suitable } \\
\text { with the } \\
\text { principl } \\
\text { e of } \\
\text { ease of } \\
\text { administ } \\
\text { ration in } \\
\text { tax } \\
\text { collectio } \\
\mathrm{n}\end{array}$ \\
\hline $\begin{array}{l}\text { Definiti } \\
\text { on of } \\
\text { low tax } \\
\text { juridict } \\
\text { ion }\end{array}$ & N/A & $\begin{array}{l}\text { Less } \\
\text { effectiv } \\
\text { e } \\
\text { because } \\
\text { CFC } \\
\text { rules are } \\
\text { applied } \\
\text { without } \\
\text { due } \\
\text { consider } \\
\text { ation of } \\
\text { the tax } \\
\text { rates in } \\
\text { the } \\
\text { countrie } \\
\text { s where } \\
\text { the } \\
\text { relevant } \\
\text { CFC are } \\
\text { located. }\end{array}$ & N/A & $\begin{array}{l}\text { Less } \\
\text { effectiv } \\
\text { e } \\
\text { because } \\
\text { CFC } \\
\text { rules are } \\
\text { applied } \\
\text { without } \\
\text { due } \\
\text { consider } \\
\text { ation of } \\
\text { the tax } \\
\text { rates in } \\
\text { the } \\
\text { countrie } \\
\mathrm{s} \text { where } \\
\text { the } \\
\text { relevant } \\
\text { CFC are } \\
\text { located }\end{array}$ \\
\hline $\begin{array}{l}\text { Exempt } \\
\text { ion }\end{array}$ & $\begin{array}{c}\text { Listing } \\
\text { busines } \\
\mathrm{s} \\
\text { entities }\end{array}$ & $\begin{array}{l}\text { Unavail } \\
\text { able } \\
\text { exempti } \\
\text { on to } \\
\text { business } \\
\text { entities } \\
\text { carrying } \\
\text { out }\end{array}$ & $\begin{array}{c}\text { Listing } \\
\text { busines } \\
s \\
\text { entities }\end{array}$ & $\begin{array}{l}\text { Unavail } \\
\text { able } \\
\text { exempti } \\
\text { on to } \\
\text { business } \\
\text { entities } \\
\text { carrying } \\
\text { out }\end{array}$ \\
\hline
\end{tabular}




\begin{tabular}{|l|l|l|l|}
\hline & genuine & & genuine \\
economi & & economi \\
c & & c \\
activity & & activity \\
and not & & and not \\
having & & having \\
tax & & tax \\
& avoidan & avoidan \\
& ce & ce \\
\hline
\end{tabular}

Based on the table above, there are quite significant differences between PMK-256 and PMK-107 in relation to the aspects of definition of control and calculation as well as CFC revenue attribution. PMK-107 is better than PMK-256 because it has less loopholes, however there are still weaknesses in PMK-107 rendering such regulation less effective in preventing tax avoidance. Such weaknesses are, among others:

\section{a. Type of control}

Based on article 2 and article 4 of PMK-107, control is defined as minimum $50 \%$ capital participation of the total directly and indirectly paid up shares in non-stock exchange overseas business entities. The definition of control that covers both direct and indirect participation has been in accordance with CFC regulation in general. The only direct control requirement will be very easy to avoid by performing control through artificial share ownership structure (Lang, Aigner, Scheuerle and Stafaner, 2004).

The type of control provided for in the CFC rules in Indonesia only covers legal control in the form of shares with the minimum amount of $50 \%$. Through de jure control, resident taxpayers can still perform control on overseas business entities for example through prerogative right in the form of capacity to appoint and dismiss the board of directors. Expansion to the type of control needs to be taken into consideration bearing in mind that control is not always performed through shares. In the FSAS (Statement of Financial Accounting Standards) Number 4 concerning Consolidated Financial Statements, there are de facto and de jure control tests to determine whether a company is capable of affecting other companies. De facto control test can be seen based on the minimum $50 \%$ direct and indirect shareholding, whereas de jure control test can be seen from several conditions, among others, together with other investors under an agreement having minimum $50 \%$ voting rights, being authorized to manage any other company's finance and operations, having the capacity to appoint and dismiss officials in a company, as well as controlling the majority of votes in a management meeting. It is not easy to apply de facto control requirement as it requires in-depth investigation, but if $\mathrm{CFC}$ rules also provide that de jure control is also required as provided for in the FSAS, avoidance of the application of CFC rules through change to the type of control will be easier to prevent.

b. Minimum ownership limit in determining joint ownership with other resident taxpayers.

The CFC rules in Indonesia do not contain provisions providing for ownership limit in determining joint ownership with other resident taxpayers. The application of considerably extensive ownership shall render control difficult because the burden of proof on ownership is on the hands of the resident taxpayers. Tax authorities shall only rely on the tax returns reported by resident taxpayers to know of the amount of shares owned by the resident taxpayers, particularly individual resident taxpayers; therefore the unavailability of minimum ownership limit shall render control difficult to perform. Provision on ownership limit needs to be provided to facilitate control and reduce the cost of administration of the resident taxpayers having insignificant amount of shares in controlled foreign companies.

c. Definition of low tax juridiction

The CFC rules in Indonesia are applied towards all overseas entities other than listed entities. This is ineffective as deferral shall only bring benefit if effective taxes overseas are lower than domestic taxes (Arnold, 1986). The application of CFC rules towards all entities controlled by resident taxpayers shall only increase the cost of taxation both to the resident taxpayers and the tax authorities. Through the tax credit existing 
in Indonesia, if the effective tax rate overseas is higher than in Indonesia, there shall not be any income. CFC rules should only be applied towards controlled entities having high risk towards tax avoidance. Risk determination can be done based on the effective tax rate applied towards overseas controlled entities. The occurrence of definition or criteria of low tax jurisdiction is important for rendering CFC rules more effective in achieving their purpose as antiavoidance rules.

\section{d. Exemption}

Article 4 of PMK-107 states that deemed dividends shall be calculated from profit after tax of overseas non-listed business entities. Based on the foregoing, CFC's income shall cover the entire income received by CFC (both passive and active). Indonesia uses entity approach in defining CFC's income. According to Pinto (2003) the entity approach focuses on the foreign entity, and in particular on the nature of its income. In the use of entity approach, there are a number of exceptions, among others, exemption of the application of CFC rules towards the $\mathrm{CFC}$ receiving their main income from genuine economic activity even though they are located or established in a country having low tax rate or having no tax rate and motive exemption, where CFC rules shall not be applied if the resident taxpayers are able to prove that the investments made in the relevant $\mathrm{CFC}$ are merely for economic purpose, and not for tax avoidance (Pinto,2013). There is weakness in the aforementioned definition because CFC rules should not have been applied towards overseas entities performing genuine economic exemption and not having tax avoidance motive. The entities that are able to prove themselves performing actual businesses and not having tax avoidance motive should have been exempted. Such exemption should have been done for the overseas entities owned by resident taxpayers to compete with other foreign companies.

\section{Comparison between the $\mathrm{CFC}$ rules in} Indonesia and in China as well as

\section{Recommendations in OECD Action Plan} 3

a. Aspect of Type of Control

There are significant differences between the CFC rules in Indonesia and in China as well as recommendations in the Action Plan 3. Indonesia only applies legal test control in the form of shares, whereas China applies legal test control and effective control. Based on article 117 of the Implementing Regulations of the Income Tax Law, the CFC rules in China expressly and clearly defines that control shall comprise direct and indirect legal control and effective control. Control test shall be performed in two stages. First, through legal control in the form of shares where the resident taxpayers in China are determined having control over overseas entities in the event of minimum $10 \%$ shareholding and more than 50\% individual or joint ownership with other resident taxpayers in China. When control test through shares is not fulfilled, control test in the form of effective control shall be performed by virtue of shares, influence owned on the company's operations, sales and purchases performed by the company. If the effective control is fulfilled, the relevant resident taxpayers shall be deemed having control therefore CFC rules shall be applied.

Related to the type of control, Recommendations in the BEPS Action Plan 3 constitute an expansion of the definition of control. The definition of control owned by the CFC rules in member states must at least comprise direct and indirect legal control and economic control. Control requirement that is limited only to direct legal control will be very easy to avoid in the application of $\mathrm{CFC}$ rules.

b. Aspect of minimum shareholding limit in determining joint ownership with other resident taxpayers

Different from Indonesia having no shareholding limit in determining joint ownership with resident taxpayers, the CFC rules in China determines minimum $10 \%$ shareholding limit where CFC rules shall be applied if the individual resident taxpayers in China has minimum $10 \%$ share capital and jointly with other resident taxpayers in China has more than 50\% 
share capital in overseas business entities. To facilitate control over CFC, the tax authorities in China are authorized to determine whether or not an overseas entity is a CFC through a special form in the form of information reporting participation of a resident enterprise in a foreign enterprise. Resident taxpayers in China are obligated to submit such special form in the event of minimum $10 \%$ shareholding, in the event of change in ownership resulting in greater shares owned in overseas entities. Based on such special form, the tax authorities in China shall notify the relevant resident taxpayers in China if the relevant overseas entities are categorized as $\mathrm{CFC}$ therefore $\mathrm{CFC}$ rules shall be applied. CFC rules shall be applied when a resident taxpayer receives a notice on whether or not the relevant overseas entity owned is a CFC, therefore the relevant resident taxpayer may become certain and clear in respect of the application of CFC rules.

Related to minimum ownership limit, the OECD has not given any recommendation, but in the Action Plan 3, the OECD has given examples of states using minimum shareholding limit.

c. Aspect of definition of low tax
jurisdiction

Different from Indonesia having no definition of low tax jurisdiction, based on article 45 of chapter 6 of the Enterprise Income Tax Law and article 118 of the Implementing Regulations of the Enterprise Income Tax Law, the CFC rules in China defines low tax jurisdiction as a state with effective tax rate less than $12.5 \%$. The occurrence definition of low tax jurisdiction shall render CFC rules more effective because they shall only be applied towards the CFC having high risk towards tax avoidance.

Related to the definition of low tax jurisdiction, the OECD Action Plan 3 recommends the use of ETR (Effective Tax Rate). CFC rules shall only be applied if the ETR applied in the countries where the CFC are located are lower than the ETR in the countries of the shareholders. The use of ETR is a characteristic of global approach.
According to Pinto (2003), global approach is an approach that focuses on overseas taxation regime based on the effective tax rate applied on the income received by shareholders. On the one hand, global approach brings more justice because it applies CFC rules based on the effective tax rates applied by the countries where there the CFC are located, but on the other hand it is potential of incurring high cost of administration due to the requirement of case by case analysis (Fajriyan,2017).

\section{d. Aspect of Exemption}

Indonesia and Chine use the same approach in defining CFC's income, namely entity approach, however, China exempts the application of CFC rules towards overseas controlled entities carrying out genuine economic activity and not having tax avoidance motive. Arnold and McIntyre $(2002,102)$ mentioned three criteria related to the CFC carrying out genuine economic activity, namely(1) the CFC established purely for business purpose, (2) the CFC having substantive presence and not serving as paper company, (3) More than a particular percentage (commonly 50 percent) of the total revenues obtained by CFC derives from the parties having no special relationship.

The CFC rules in China defines the entire income received by $\mathrm{CFC}$ (both from active and passive activities), but if the CFC can prove that their main activity is active business operation, CFC rules shall not be applied. Such verification shall be conducted by requesting for evidence to the resident taxpayers that $50 \%$ of the CFC's annual income is obtained from active business activities. In addition, exemption to the application of CFC rules shall also be given to the CFC located in white list countries without considering the effective tax rates applied in the relevant countries. The white list countries comprise, among others, Australia, Canada, Germany, India, Italiy, Japan, New Zealand, Norwegia, South Africa, United Kingdom and the United States of America. 
Related to exemption in the definition of CFC's income, the BEPS Action Plan 3 does not give any recommendation. Every country is given freedom to define CFC's income pursuant to the risks faced. Recommendation on exemption in the application of CFC rules is only for the CFC located in the countries having higher ETR than the ETR in the countries of the shareholders.

To easier understanding of the comparison between the provisions in the $\mathrm{CFC}$ rules in China and in Indonesia as well as the Recommendations in the BEPS Action Plan 3, comparison matrix is provided below:

Table 2

Matrix of comparison of the CFC rules in Indonesia and in China as well as Recommendations in the OECD Action Plan 3 for strengthening the $\mathrm{CFC}$ rules of member countries

\begin{tabular}{|c|c|c|c|c|c|}
\hline \multirow[t]{2}{*}{$\mathbf{N}$} & \multirow{2}{*}{\multicolumn{2}{|c|}{$\begin{array}{l}\text { Provisions in } \\
\text { CFC rules }\end{array}$}} & \multicolumn{2}{|c|}{ Countries } & \multirow{2}{*}{$\begin{array}{l}\text { OECD } \\
\text { Action } \\
\text { Plan } 3\end{array}$} \\
\hline & & & Ind & Chin & \\
\hline \multirow[t]{2}{*}{1} & \multirow[t]{2}{*}{$\begin{array}{l}\text { Aspect } \\
\text { of } \\
\text { control }\end{array}$} & $\begin{array}{c}\text { Natur } \\
\text { e of } \\
\text { contr } \\
\text { ol }\end{array}$ & $\begin{array}{c}\text { Dire } \\
\text { ct } \\
\text { and } \\
\text { indir } \\
\text { ect }\end{array}$ & $\begin{array}{c}\text { Direc } \\
\mathrm{t} \text { and } \\
\text { indire } \\
\mathrm{ct}\end{array}$ & $\begin{array}{l}\text { Direct } \\
\text { and } \\
\text { indirect }\end{array}$ \\
\hline & & $\begin{array}{l}\text { Type } \\
\text { of } \\
\text { contr } \\
\text { ol }\end{array}$ & $\begin{array}{l}\text { Leg } \\
\text { al } \\
\text { cont } \\
\text { rol } \\
\text { in } \\
\text { the } \\
\text { for } \\
\text { m of } \\
\text { shar } \\
\text { es }\end{array}$ & $\begin{array}{c}\text { Legal } \\
\text { contr } \\
\text { ol in } \\
\text { the } \\
\text { form } \\
\text { of } \\
\text { share } \\
\mathrm{s} \text { and } \\
\text { effect } \\
\text { ive } \\
\text { contr } \\
\text { ol }\end{array}$ & $\begin{array}{l}\text { Legal } \\
\text { control } \\
\text { in the } \\
\text { form of } \\
\text { shares } \\
\text { and } \\
\text { econo } \\
\text { mic } \\
\text { control }\end{array}$ \\
\hline \multirow[t]{2}{*}{2} & \multirow{2}{*}{$\begin{array}{l}\text { Aspect } \\
\text { of } \\
\text { Shareh } \\
\text { olding } \\
\text { Limit } \\
\text { in } \\
\text { determ } \\
\text { ining }\end{array}$} & $\begin{array}{l}\text { Thres } \\
\text { hold } \\
\end{array}$ & N/A & $10 \%$ & \multirow[b]{2}{*}{$\begin{array}{l}\text { Unavai } \\
\text { lable } \\
\text { definite } \\
\text { recom } \\
\text { mendat } \\
\text { ion on }\end{array}$} \\
\hline & & $\begin{array}{l}\text { Share } \\
\text { holdi } \\
\text { ng } \\
\text { data }\end{array}$ & $\begin{array}{c}\text { Tax } \\
\text { Retu } \\
\text { rn }\end{array}$ & $\begin{array}{l}\text { Speci } \\
\text { al } \\
\text { form } \\
\text { in the } \\
\text { form }\end{array}$ & \\
\hline
\end{tabular}

\begin{tabular}{|c|c|c|c|c|c|}
\hline & $\begin{array}{l}\text { joint } \\
\text { owners } \\
\text { hip } \\
\text { bersam } \\
\text { a }\end{array}$ & & & $\begin{array}{c}\text { of } \\
\text { infor } \\
\text { matio } \\
n \\
\text { repor } \\
\text { ting } \\
\text { partic } \\
\text { ipatio } \\
\text { n of a } \\
\text { resid } \\
\text { ent } \\
\text { enter } \\
\text { prise } \\
\text { in a } \\
\text { forei } \\
\text { gn } \\
\text { enter } \\
\text { prise. }\end{array}$ & $\begin{array}{l}\text { owners } \\
\text { hip } \\
\text { limit }\end{array}$ \\
\hline 3 & \multicolumn{2}{|c|}{$\begin{array}{c}\text { Aspect of } \\
\text { definition of } \\
\text { low tax } \\
\text { juridiction }\end{array}$} & N/A & $\begin{array}{c}\text { A } \\
\text { count } \\
\text { ry } \\
\text { with } \\
\text { effect } \\
\text { ive } \\
\text { tax } \\
\text { rate } \\
\text { less } \\
\text { than } \\
12.5 \\
\% .\end{array}$ & $\begin{array}{c}\text { Using } \\
\text { ETR as } \\
\text { determi } \\
\text { nant in } \\
\text { the } \\
\text { applica } \\
\text { tion of } \\
\text { CFC } \\
\text { rules }\end{array}$ \\
\hline 4 & $\begin{array}{l}\text { Aspe } \\
\text { ct of } \\
\text { Exem } \\
\text { ption }\end{array}$ & $\begin{array}{l}\text { Definit } \\
\text { ion of } \\
\text { CFC's } \\
\text { income }\end{array}$ & N/A & $\begin{array}{c}\text { Appl } \\
\text { ying } \\
\text { exem } \\
\text { ption } \\
\text { to the } \\
\text { CFC } \\
\text { carryi } \\
\text { ng } \\
\text { out } \\
\text { genui } \\
\text { ne } \\
\text { econ } \\
\text { omic } \\
\text { activi } \\
\text { ty } \\
\text { and } \\
\text { not } \\
\text { havin } \\
\text { g tax } \\
\text { avoid } \\
\text { ance }\end{array}$ & $\begin{array}{l}\text { Exemp } \\
\text { tion of } \\
\text { CFC } \\
\text { rules } \\
\text { toward } \\
\text { s the } \\
\text { CFC } \\
\text { located } \\
\text { in the } \\
\text { countri } \\
\text { es } \\
\text { having } \\
\text { higher } \\
\text { ETR } \\
\text { than } \\
\text { the } \\
\text { ETR in } \\
\text { the } \\
\text { countri } \\
\text { es of }\end{array}$ \\
\hline
\end{tabular}




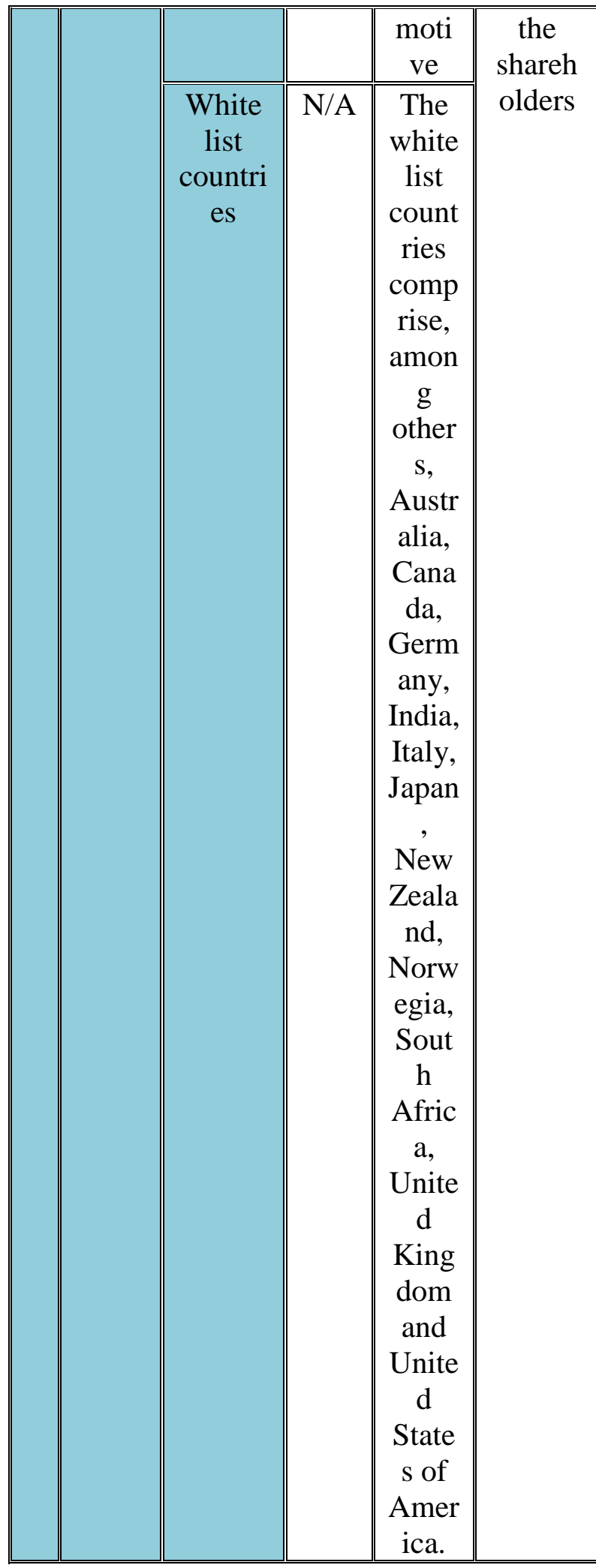

Source: processed by researcher based on the conducted research

\section{CONCLUSION}

Seen from the 4 aspects, namely the aspect of control, the aspect of shareholding limit in determining joint ownership with other resident taxpayers, the aspect of definition of low tax jurisdiction, and the aspect of exemption, it is known that the CFC rules in Indonesia are considered weak if compared to the $\mathrm{CFC}$ rules in China and the Recommendations in the OECD Action Plan 3 because the type of control of the CFC rules in Indonesia only covers legal control in the form of shares, does not provide ownership limit resulting in difficulty in performing control and does not provide exemption towards the entities carrying out actual business activities.

To render the CFC in Indonesia effective and efficient in preventing tax avoidance, remedies to the weaknesses in CFC rules can be performed by way of;

1. Applying control test that is not based only on legal control in the form of shares, providing for shareholding limit in determining joint ownership with other resident taxpayers, making definition of low tax jurisdiction, and applying genuine economic exemption and motive exemption.

2. a. There are provisions in the CFC rules in China that are proven effective in preventing tax avoidance through CFC, therefore need to be taken into consideration for adoption, namely among others the application of control test based on direct and indirect legal control test and effective control, provisions on shareholding limit in determining joint ownership with other resident taxpayers, provisions on low tax jurisdiction, the application of genuine economic exemption and motive exemption.

b. There are recommendations in the BEPS Action Plan 3 that need to be taken into consideration for adoption, among others, to expand the definition of control by way of expanding the type of control that covers not only legal control in the form of shares but also direct and indirect economic control and making definition of low tax 
jurisdiction based on comparison of the ETR in the countries where the CFC are located and the countries of the shareholders.

\section{REFERENCES}

Arnold, Brian. J. The Taxation of Controlled Foreign Corporation: An International Comparison Canadia Tax Paper. 1986

Arnold, Brian .J and Michael J.McIntyre. International Tax Primer. The Hague:

Kluwer Law International. 2002

Arnold, Brian .J and Patrick Dibout. International Fiscal Association, Limit on the use of low tax regimes by multinational business current measure and emerging trends. The Hague: Kluwer Law International.2001

Asqolani, M. Penerapan Controlled Foreign Companies sebagai Anti TaxAvoidance. Majalah Inside Tax. Edisi Perkenalan September 2007.

Fajriyan, Nur Afianti. Analisis Rencana Aksi 3 Base Erosion And Profit Shifting Dalam Upaya Memperkuat Regulasi Controlled Foreign Companies Untuk Menangkal Penghindaran Pajak (Suatu Kajian Atas Regulasi CFC Indonesia Dan Tiongkok). Tesis Program Pascasarjana Ilmu Administrasi. FIA Universita Indonesia. 2017

Gunadi. Pajak Internasional. Jakarta: Lembaga Penerbit FE UI. 2007

Lang, Michael, Hans-Jorgen Aigner, Ulrich Scheuerle, and Markus Stefaner. CFC Legislation, Tax Treaties and EC Law. The Hague; Kluwer Law International. 2004

Pinto, Carlos. Tax Competition Of EU Law. The Hague; Kluwer Law Internasional. 2003.

Rahayu, Ning. Praktik Penghindaran Pajak (Tax Avoidance) Pada Foreign Direct Investment Yang Berbentuk Subsidiary Company (PT.PMA) Di Indonesia (Suatu Kajian Tentang Kebijakan Anti Avoidance Rule ). Disertasi Program Pascasarjana Ilmu
Administrasi. FISIP Universita Indonesia. 2008

Rohatgi, Roy. Basic International Taxation Volume 1:Principles. London:BNA International Inc. 2005 